\title{
Online Collective Poetry Recitation Performance during COVID-19 Outbreak
}

\author{
新冠肺炎疫情爆发下的集体隔空诗歌朗诵 \\ Yongwen Peng 彭勇文 \\ Shanghai Theatre Academy, China
}

\begin{abstract}
In human history, the impact of epidemic outbreaks on human society is much worse than that of other natural disaster because the effects of viruses are often invisible in the early stages. Viruses silently sicken or kill thousands of people, collapse families, create panic, and even damage society's function. With the outbreak of COVID-19 in late 2019, interesting forms of online collective poetry recitation performance emerged from different parts of China since Feburary 2020. This article presents three online collective poetry recitation works so as to analyze their two functions: as a theraputic way to deal with people's fear of the virus and to generate positive emotions, such as love and courage, and as a ritual to strengthen people's sense of identity as Chinese, bringing hundreds of millions of Chinese people together and gathering a powerful force to overcome the epidemic.
\end{abstract}

Keywords: online collective poetry recitation, COVID-19, ritual, therapy

\section{摘要}

人类历史上的各种瘟疫灾害对人类社会的影响，常常超过了其他自然灾害，因为造成瘟 疫的病毒常常看不见，却悄无声息地让成干上万人的病倒或死去，给民众带来巨大的恐 慌，让社会无法正常运行。新冠肺炎疫情爆发以来，尤其2020年2月后，中国多地出现 了在网络媒体上开展的集体隔空诗歌朗诵的有趣形式。本文以三个集体性“隔空朗诵” 作品为案例，分析了这种集体艺术表达方式的两大功能 : 作为治疗的方式，帮助朗读者 自己和他人释放对病毒的恐惧，激发和调动爱、勇气等正面情绪；作为一种仪式表演， 强化中国人的身份意识，将亿万中国人凝聚在一起，形成战胜疫情的强大力量。

关键词：集体隔空诗歌朗诵，新冠肺炎病毒，仪式、治疗

In human history, the impact of epidemic outbreaks on human society is much worse than that of other natural disaster because the effects of viruses are often invisible in the early stages. Viruses silently sicken thousands of people, collapse families, create panic, and even damage society's function. With the outbreak of COVID-19 in late 2019, interesting forms of online collective poetry recitation performance emerged from different parts of China since Feburary 2020. It effectively supports the public's

This article is sponsored by China National Key Research Project in Arts Studies "Frontiers of Contemporary Theatre Theories in the West" (No.18ZD06). 
emotional expression and therapy, and strengthens people's identity and unity to stay strong throughout the outbreak. Let's see how it started.

\section{Millions of people were forced into "epidemic mode"}

Although the outbreak of COVID-19 started more than a month before the 2020 Chinese Lunar New Year, millions of Chinese still traveled home for the new year, visiting relatives and friends and celebrating the most important festival of the year. As the number of people being affected by the virus was steadily increasing, the city of Wuhan, and later the whole province of Hubei, had to shut down its public transportation system at 10:00 a.m. on January 23, 2020. The city, which has a population of 10 million people, was instantly "closed." The people of Wuhan were not allowed to leave the city, and the people outside were not allowed to enter, except for the military and medical workers who came from all over the country to provide support. Subsequently, people in cities and villages across the country were asked to stay at home day and night, and all activities in public places were cancelled. Hundreds of millions of Chinese were suddenly forced into a different mode of life during the epidemic and began to find ways to spend the tedious time at home.

This unprecedented state of life is reflected in the poem "Fighting Virus, Our Hearts and Hands Are Linked" by KsiongYuqing, a poet in Yichun, Jiangxi Province:

When we pack up the year's weariness

Enjoy the rare peace of the holiday

When we prepare the red lantern

Look forward to family reunion

A long-planned ghost

Fly out of Pandora's box

With the madness of revenge

Launch a sudden attack on the human race

A city collapsed

Everything changed

The street was very, very quiet

The occasional passer by armed with a mask

Looking alert and wary

All closed, closed, stopped

No rhythm of dance ladies at city squares

No laughter of the children in the park

No voices of happy New Year wishes between families and friends

People are hijacked by the epidemic demon

Most cities became empty

In the "empty cities," people seem to return to the ancient "cave' life. Doors were closed, and people could only look at the outside world through the window. Fortunately, the 
Internet in China has entered the $5 \mathrm{G}$ era ahead of time. Advanced communication technology enables people to conveniently obtain various kinds of knowledge and entertainment online. They can keep in touch and communicate with relatives and friends through WeChat or other social media. However, the dramatic changes in life patterns are putting adults and children in millions of families under unprecedented physical and mental stress. Their indoor life, day and night, is very monotonous and depressing. Many people's body clocks and daily routines are disrupted, and their living space is drastically compressed. People feel physically and mentally tired after watching TV or playing on their mobile phones for a long time. In the face of the increasing number of confirmed cases and deaths reported by the mainstream news media and all kinds of information, whether true or false, on the Internet, people are very anxious and worried.

\section{Online collective poetry recitation came into being}

Art has shown its positive values and its great impact on the lives of the people in the epidemic. Chinese live-streaming platforms as well as many short video mobile websites or applications have seen a sharp increase in the number of registered users. People are posting videos of themselves singing, dancing, playing games, performing comedy skits, and even acting funny at home, entertaining themselves as well as others. People need to release their worries and anxieties and/or alleviate the depression and boredom of life through a variety of expressions. Chinese artists and poets become very active and create all kinds of artistic works responding to the needs of the times and the people. Poetry, relying on human language, is the most easy, direct, and effective form of artistic expression. It helps the Chinese people hear each other's voice, feel each other's care and support, and help others gain faith and strength to overcome difficulties.

\section{Group poetry recitation on the CCTV Spring Festival Gala}

Collective poetry recitation first appeared on CCTV, the national mainstream media, which aroused strong resonance among the people. On the afternoon of January 24, less than four hours before the start of the CCTV Spring Festival Gala in 2020, the director of the gala added a recitation program. Six famous CCTV news anchors read the poem "Bridge of Love" under the gaze of hundreds of millions of Chinese viewers and paid a New Year's call to the white angels, the doctors and nurses on the frontline of epidemic prevention, and to all the people of Hubei Province and the city of Wuhan. The concern of the whole nation for the people of Hubei is revealed between the lines. "We're celebrating Chinese New Year, but you're helping us pass the difficulties," "Isolating virus, but not isolating love," and so on, which deeply moved hundreds of millions of viewers and immediately became buzzwords of the Chinese people, spreading on WeChat, circles of friends, and various social media. The positive emotional energy contained in these poems has turned into warm currents, transformed people's negative emotions caused by the epidemic, and lifted the confidence of the Chinese people to unite as one and overcome the epidemic. 


\section{Online collective poetry recitation in WeChat}

China has a long tradition of poetry, and people love to write and recite poems. During important moments or in the face of major events, poets release their rich and strong emotions through poetry to express themselves and the aspirations of the people. The collective recitation of CCTV's famous anchors in the spring evening was like a clarion, which ignited the passion of poets around the country. All kinds of poems related to the theme of "fighting against the epidemic" were published continuously through various channels, both in written and audio forms. People not only read by themselves, but they also hope to read with their friends; thus, they spontaneously organized a WeChat group to record their recitation performance and transmit through the network. The online collective poetry recitation came into being, which not only has a ritualistic meaning, but also has expressive, therapeutic value.

Launched in 2011, WeChat has become the most important social media in China, with nearly 1.2 billion active accounts by the end of 2019. People form various groups or communities in the application and it is used in all aspects of work and life. The form of online recitation relies on the WeChat platform's strong communication and collaboration ability, enabling people who are separated from each other and living in different places to gather their voices together to form an impressive collective poetic recitation.

First, the author organized a small online poetry recitation in the Shanghai Theatre Academy class he taught, class 2018, which majors in drama education. Five students immediately volunteered to sign up after the author told the class his idea. They were assigned a stanza of a poem, which they practiced at length until they can recite it with the right tone and emotion. They recorded their part on their mobile phones and sent their voice record to the author in the WeChat group. Finally, the author consolidated the

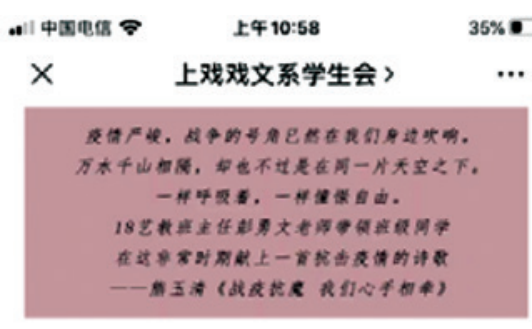

䐓诵: 18艺教师生

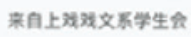
$00: 00$ ง)

战疫抗魔我们心手相牵

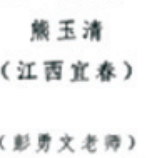

当我们收拾起一年的素意 亨受希假期难得的平解 当我们准备好大红的灯笔 迎接着亲人久违的团聚

Picture of the Publication of the author and his student's recitation on Wechat audio and applied music. Although the students' voice seems immature, their reading ability uneven, and the cell phone recording had a variety of background noises, their voices during the online recitation connected them to their own being as well as to the audience, teachers, and students (http://xima.tv/gSbDNv).

Subsequently, the author participated in an online collective poetry recitation with the poem "We Are All from Hubei" organized by the union of Shanghai Theatre Academy. The organizer, Prof. Wang, sent the notice to her colleague in the teachers' 


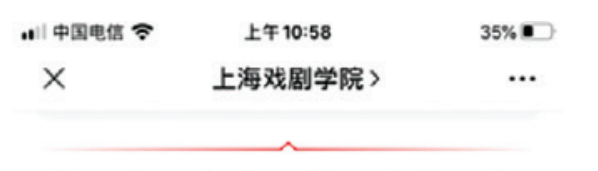

《我是湖北人》

作者：晓吾

朗诵: 上海戏剧学院教师、学生、校友

声音合成: 马联、刘婉玲

音乐合成: 梅梅

(注: “为湖北籍)

\section{湖北在哪里?}

淊滔江水出三峡。

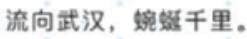

过江西、安徽、江苏、上海,

滋苏半壁繁华, 奔嵒入东海。

(王苏、贾丘" 、王一楠、碚光㢭)

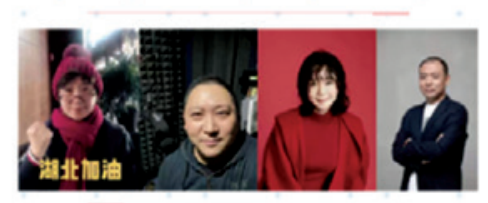

Picture of the Publication of Shanghai

Theatre Academy's teachers and

student's recitation on Wechat
WeChat group, and soon, 71 teachers, students, and alumni answered the call and finished their recording of the recitation in 2 days. The theme "Every Chinese person is just like a native of Hubei" was constantly reinforced in the poem by every recitation participant, which expressed the strong will and feelings of the students, teachers, and alumni of Shanghai Theatre Academy to stand together with the people of Hubei (http://xima.tv/1SZPpS).

A larger group recitation was performed by the Shanghai Recitation Association. Founded in 2017, the association has nearly 400 members from all walks of life. The voices of 139 recitation participants represent the voice of the people of Shanghai and tell the people in Hubei and the whole country that we are a community with a shared future. In the face of the serious epidemic, 139 members signed up in 10 hours on February 2, 2020, at the initiative of the chairman, Lu Cheng, and participated in the online recitation activity of the association. The recitation was a long poem by Shanghai poet Huang Yuyan, "China Will Prove Againdedicated to all the heroes of the prevention, control of the epidemic in 2020." Chen Youqi, the vice president of the association, was responsible for the copywriting work before the poetry recitation, distributing different stanzas of the long poem to different people, including individual recitation and multiple recitation. All 139 recitation participants, scattered throughout the country, expressed their passion and faith through their voices. To ensure that the voice of each person has a good effect and to coordinate the collective voice of the group, another member of the association, Mr. Zhou Lin constantly communicated with the recitation participants through WeChat. In the end, Li Peikang, a director of the association and a master of film and television production, synthesized the voices of the people and added music and background pictures or videos. Relying on the patience and meticulous work of the whole team, the online poetry recitation was finally and successfully completed. The 13-minute-long performance of online poetry recitation was transmitted through the Internet, causing thousands of netizens to forward and "thumb up" the video. This kind of online poetry recitation did not happen in Shanghai only. You can easily find many works like this on the Internet.

\section{The functions of online collective poetry recitation}

Some people have commented that the literature and artworks addressing the epidemic (including the online collective poetry recitation) do not really count because the doctors 
and nurses who are in the forefront of the fighting in the outbreak do not have any time to listen to or see these works of art, that what they need most is a variety of protective materials and medicines, tangible things that have real value.

The author likewise believes that the medical staff on the frontlines are indeed working intensely and might not have time to view or watch the online recitations or other artistic works. However, they are also humans and need to rest and relax. They not only need to supplement their nutrition, but they also need food for their hearts in order to strengthen their spirits. Recently, the authorities in charge of epidemic control have proposed that medical institutions should not only provide material support for medical workers, but also pay attention to their humanistic care and psychological support. The online poetry recitations and other artistic "anti-epidemic" works that are widely spreading on the Internet did express deep respect for medical workers from all walks of life and strengthened the unity of the Chinese people. These artistic works have more values. They were created not only for the medical staff, but also for the artists and participants themselves, with functions of rituals and healing.

According to Richard Schechner (2005), the founder of performance studies, human performance is mainly divided into five fields, namely aesthetic, game ritual, mass, and social performances. There are seven functions of performance: to entertain, to create beauty, to educate, to heal, to establish or change identity, to create or sustain community, to deal with fear or divine things. According to this classification, the online collective poetry recitation belongs to ritual performance and its function mainly includes

1. To deal with people's fear of the virus and to heal both themselves and others, helping individuals or groups to release inner fear, anxiety, and other negative emotions, and to generate positive emotions, such as love and courage. It is a spontaneous group self-poetry therapy. It also enables people from all walks of life who see these works to gain a strong resonance.

2. To strengthen people's sense of identity as Chinese, bringing hundreds of millions of Chinese people together and gathering a powerful force to overcome the epidemic. As the host of Tianjin radio described the collective recitation: "In the face of the epidemic, confidence is a special dose of 'vaccine.' Wuhan, we fight together! China, we fight together! At this moment, our destinies are linked. Let us unite as one and win this common war together!"

When an important event or moment happens to an individual or group of people, rituals are often held to express the significance of the event, to reflect the value of the moment, and to leave a deep imprint on history. This is true of rituals, such as comingof-age ceremony, marriage, flag-raising, and military parades. In rituals, people step out of their busy daily lives and into the specific space and time of rituals, shifting from one role to another, from the world of reality and utility to the world of spirit and culture. In the ancient time, when some parts of China were faced with disasters such as severe drought, the kings, in addition to sending capable ministers to lead the people in dealing with the disaster, often held ceremonies in some sacred temples or 
places to pray for rain and mercy from heaven. Since the founding of the People's Republic of China, our country has no longer held such activities. In my memory, the last national ceremony led by top national leaders and attended by many people was the National Memorial in May 19, 2008. It was the seventh day after the massive Wenchuan earthquake in May 12, 2008. Hundreds of millions of people bowed their head and kept silent for 3 minutes, mourning the nearly 70,000 dead and condoling with the families of the casualties. This ceremony fulfilled two of the basic functions mentioned above, to deal with the fear of the earthquake and heal the psychological pain and to unite the people as one.

\section{Conclusion}

As Tedros Adhanom Ghebreyesu, the director-general of World Health Organization, said in an interview with Guangzhou Daily on February 13, 2020, "[t] he prevention and control measures taken by China in response to the outbreak of COVID-19 are really unprecedented and effective, preventing the spread of the disease to the greatest extent" (From the Website of Guangzhou Daily). Indeed, no country has been able to mobilize such huge medical and social resources to combat the virus, and no government has been able to call on such a large population to lock themselves in their homes in such a short time. China can do this not only because of its institutional advantages or the strong power of the central and local governments, but also because of its cultural advantages. The Chinese people have always attached great importance to collectivism and have a fine tradition of "when one part of the country is in trouble, the other parts always provide support in a short time." In the face of the COVID-19 disaster, the heart of every Chinese person contains a kind of centripetal force. These various artworks addressing the disaster, including online collective poetry recitation, is the ritual performance of artists and ordinary people around China, showing that the people from all walks of life are all in action with the same emotional vibrations.

\section{About the Author}

Dr. Yongwen Peng is an associate professor in Shanghai Theatre Academy. He has a PhD in performance studies, and his work focuses on arts education and therapy. His book Theatre and Training (2011) is the first of its kind in China, and he has translated The Couch and the Stage: Integrating Words and Action in Psychotherapy (2012), a book on drama therapy by Professor Robert Landy of New York University. He is a board member of the Chinese Arts Therapist Group and a member of the National Association for Poetry Therapy. He is also a voice artist and has practiced tai-chi for 20 years, as a member of the second generation of the Chen-style tai-chi master Wang Shi'an.

\section{References}

XIAO, Huanhuan, The Director-general of WHO said: China has taken effective measures to stop the outbreak of Covid-19, Website of Guangzhou Daily, https://news.dayoo.com/ gzrbyc/202002/13/158752_53119262.htm

Schechner, R. (2005). Past, now and future of performance studies. Theatre Arts Journal, 5, 5. 